\title{
Effect of resveratrol on mouse ovarian vitrification and transplantation
}

\author{
Dalin Wang ${ }^{1,2}$, Menghui Geng ${ }^{3}$, Dongying Gan ${ }^{3}$, Gege Han ${ }^{3}$, Gao Gao ${ }^{4}$, Aying Xing ${ }^{3}$, Yugui Cui ${ }^{1}$ and Yanqiu Hu ${ }^{1,5^{*}}$
}

\begin{abstract}
Background: After ovarian tissue transplantation, ischemia-reperfusion injury and free radicals cause follicle depletion and apoptosis. Therefore, the use of antioxidants to reduce the production of free radicals is an important method to address the consequences of ischemia-reperfusion injury. Resveratrol is a natural active polyphenol compound with anti-inflammatory, antitumor, strong antioxidant and anti-free radical properties. The aim of this study was to investigate whether resveratrol could improve the effect of autologous ovarian transplantation after cryopreserve-thawn mouse ovarian tissue.

Methods: Whole-ovary vitrification and autotransplantation models were used to investigate the effects of resveratrol. Six-week-old female mice from the Institute of Cancer Research (ICR) were subjected to vitrification. All ovaries were preserved in liquid nitrogen for 1 week before being thawed. After thawing, ovarian tissues were autotransplanted in the bilateral kidney capsules. Mice $(n=72)$ were randomly divided into four groups to determine the optimal concentration of resveratrol (experiment I).

Treatments were given as follows: saline, $5 \mathrm{mg} / \mathrm{kg}$ resveratrol, $15 \mathrm{mg} / \mathrm{kg}$ resveratrol and $45 \mathrm{mg} / \mathrm{kg}$ resveratrol, which were administered orally for one week. Grafted ovaries were collected for analysis on days 3, 7, and 21 after transplantation. Ovarian follicle morphology was assessed by hematoxylin and eosin staining. Serum FSH and $E_{2}$ levels were measured to estimate the transplanted ovarian reserve and endocrine function. Other mice were randomly divided into two groups — saline and $45 \mathrm{mg} / \mathrm{kg}$ resveratrol to further evaluate the effect of resveratrol and explore the mechanisms underlying this effect (experiment II). Ovarian follicle apoptosis was assessed by terminal deoxynucleotidyl transferase-mediated dUTP nick-end labeling (TUNEL) assays. Immunohistochemistry, qRT-PCR and western blotting (MDA, SOD, NF-kB, IL-6 and SIRT1) were used to explore the mechanisms of resveratrol. Moreover, oocytes derived from autotransplanted ovaries at 21 days were cultured and fertilized in vitro.

(Continued on next page)
\end{abstract}

\footnotetext{
* Correspondence: huyanqiu78@163.com

${ }^{1}$ State Key Laboratory of Reproductive Medicine, Clinical Center of

Reproductive Medicine, First Affiliated Hospital, Nanjing Medical University,

Nanjing 210029, Jiangsu Province, China

${ }^{5}$ Reproductive Medicine Center of Northern Jiangsu People's Hospital,

Yangzhou University, Yangzhou 225000, Jiangsu Province, China

Full list of author information is available at the end of the article
}

(c) The Author(s). 2021 Open Access This article is licensed under a Creative Commons Attribution 4.0 International License, which permits use, sharing, adaptation, distribution and reproduction in any medium or format, as long as you give appropriate credit to the original author(s) and the source, provide a link to the Creative Commons licence, and indicate if changes were made. The images or other third party material in this article are included in the article's Creative Commons licence, unless indicated otherwise in a credit line to the material. If material is not included in the article's Creative Commons licence and your intended use is not permitted by statutory regulation or exceeds the permitted use, you will need to obtain permission directly from the copyright holder. To view a copy of this licence, visit http://creativecommons.org/licenses/by/4.0/. The Creative Commons Public Domain Dedication waiver (http://creativecommons.org/publicdomain/zero/1.0/) applies to the data made available in this article, unless otherwise stated in a credit line to the data. 
(Continued from previous page)

Results: The proportions of morphologically normal (G1) follicles at 3, 7 and 21 days were significantly higher in the $45 \mathrm{mg} / \mathrm{kg}$ resveratrol group than in the saline group. The TUNEL-stained follicles (\%) at 7 days were significantly decreased in the $45 \mathrm{mg} / \mathrm{kg}$ resveratrol group compared with the saline group. Western blot analysis revealed that SOD2 and SIRT1 levels were significantly higher in the $45 \mathrm{mg} / \mathrm{kg}$ resveratrol group than in the saline group at day 7 and that MDA and NF-KB levels were lower in the saline group on day 3. Likewise, IL-6 was lower in the saline group on day 7. These results are basically consistent with the qRT-PCR results. In addition, the mean number of retrieved oocytes and fertilization and cleavage were significantly increased in the $45 \mathrm{mg} / \mathrm{kg}$ resveratrol group compared with the saline group.

Conclusions: Administration of resveratrol could improve the quality of cryopreserved mouse ovarian tissue after transplantation and the embryo outcome, through anti-inflammatory and antioxidative mechanisms.

Keywords: Ovarian tissue, Transplantation, Vitrification, Resveratrol, Ischemic injury

\section{Background}

Diagnostic and treatment methods for cancer have dramatically improved over the past decades. However, many survivors develop early menopause, premature ovarian failure and infertility because of chemotherapy and radiotherapy $[1,2]$. As the number of cancer patients increases, fertility preservation has become increasingly important to improve survivor quality of life and preserve fertility [3]. Currently, ovarian tissue (OT) cryopreservation and transplantation [4] represent the most effective option for fertility preservation for children, adolescents or women who cannot postpone chemotherapy and radiotherapy [5]. Many studies [2, 6] have indicated that OT cryopreservation and transplantation can improve fertility preservation and restoration. This strategy has resulted in more than 200 live births $[7,8]$. Unfortunately, in OT transplantation without surgical vascular anastomosis, more than $70 \%$ of primordial follicles [9] are lost due to early ischemia injury between transplantation and revascularization [10]. Moreover, early ischemia-reperfusion injury and free radical and oxidative damage can cause oocyte, granulosa cell and membrane lipid damage or apoptosis [11]. These changes will increase microvascular permeability and OT swelling and activate inflammatory responses through activation of adhesion molecules and enhanced cytokine production. Reactive oxygen species (ROS) directly cause oxidative damage to nucleic acids, proteins, lipids and other cellular macromolecules in ischemic tissues $[12,13]$. Therefore, the use of antioxidants to reduce the production of free radicals can be considered an important strategy to address the consequences of ischemia-reperfusion injury after OT autotransplantation [14]. To date, several attempts have been made to improve follicle survival in grafted OT $[15,16]$. Various antioxidants, such as vitamin E [17], N-acetylcysteine [18], and erythropoietin [19], have been shown to yield some improvement in follicle apoptosis and lipid peroxidation. However, no long-term follow-up of grafted human OT has been performed, and further optimization studies are required to improve tissue grafting.

Resveratrol (trans-3.5,40-trihydroxystilbene) is a natural active polyphenol compound produced by plants and is primarily found in red wine, peanuts and polydatin [20]. This compound has been reported to have a wide variety of pharmacological properties, such as antiinflammatory, antitumor, strong antioxidant and antifree radical activities [21]. In particular, resveratrol can enhance the endogenous antioxidant system of cells and the reactive oxygen species scavenging function [22]. Many pathological conditions resulting from ischemiareperfusion injury was believed to be preventable by resveratrol, which can reduce IL- 1 , IL- 6 and TNF- $\beta$ levels by downregulating the expression of NF- $\mathrm{BB}$. The ability of resveratrol to suppress inflammatory indicators could reduce ovaries damage against toxicity and ischemiareperfusion. Moreover, resveratrol has several effects on reproductive physiology, including maintenance of the ovarian reserve [23, 24] and protection against agingrelated infertility [25]. Likewise, resveratrol supported the growth of human ovarian follicles in an in vitro culture model [26].

Based on findings from previous studies, this study aimed to investigate the effects of resveratrol on ischemia-reperfusion injury after autologous ovarian transplantation and to evaluate its effects on the ovarian graft survival rate and function and follicular development and associated mechanisms.

\section{Methods \\ Animals}

A total of 176 female mice 6-8 weeks-old from Institute of Cancer Research (ICR) mice (Yangzhou University Comparative Medicine Centre) were housed under standard conditions of temperature $\left(23^{\circ} \mathrm{C} \pm 2{ }^{\circ} \mathrm{C}\right)$, relative humidity $(65 \% \pm 5 \%)$, and a 12 -h light/dark cycle in Table 1 . Food and water were provided ad libitum. The experimental protocols and animal handling procedures 
Table 1 Schematic for the study design

\begin{tabular}{|c|c|c|c|c|c|c|}
\hline & Methods & $\begin{array}{l}\text { Day (after } \\
\text { transplantation) }\end{array}$ & $\begin{array}{l}\text { Saline (number of } \\
\text { mice) }\end{array}$ & $\begin{array}{l}5 \mathrm{mg} / \mathrm{kg} \text { (number of } \\
\text { mice) }\end{array}$ & $\begin{array}{l}15 \mathrm{mg} / \mathrm{kg} \text { (number of } \\
\text { mice) }\end{array}$ & $\begin{array}{l}45 \mathrm{mg} / \mathrm{kg} \text { (number of } \\
\text { mice) }\end{array}$ \\
\hline Fresh & 6 & & & & & \\
\hline vitrification & 6 & & & & & \\
\hline \multirow[t]{3}{*}{ Experimentl } & & $3 d$ & 6 & 6 & 6 & 6 \\
\hline & $\mathrm{HE} / \mathrm{E}_{2} / \mathrm{FSH}$ & $7 d$ & 6 & 6 & 6 & 6 \\
\hline & & $21 d$ & 6 & 6 & 6 & 6 \\
\hline \multirow[t]{7}{*}{ Experimentll } & TUNEL/ & $3 d$ & 6 & & & 6 \\
\hline & & $7 d$ & 6 & & & 6 \\
\hline & Western & $3 d$ & 6 & & & 6 \\
\hline & & $7 d$ & 6 & & & 6 \\
\hline & RT-PCR & $3 d$ & 8 & & & 8 \\
\hline & & $7 d$ & 8 & & & 8 \\
\hline & IVM/IVF & $21 d$ & 6 & & & 6 \\
\hline
\end{tabular}

Experiment I Evaluation of the best concentration of resveratrol, Experiment I/ Further evaluation of the effects of resveratrol and exploration of the mechanisms

were approved and monitored by the Institutional Animal Care and Use Committee (IACUC) of Yangzhou University (SYXK (SU)2017-0044).

\section{Ovarian tissue vitrification and thawing}

Mice $(n=6)$ were anesthetized by intraperitoneal (IP) injection of a solution of ketamine $(0.15 \mathrm{mg} / \mathrm{g}$ of body weight) and xylazine $(0.016 \mathrm{mg} / \mathrm{g}$ of body weight). Both ovaries were removed and freed of fat. Ovaries were vitrified according to the protocols described by Youmetal [27].. Briefly, intact OT was serially exposed to equilibration solution (ES) for $10 \mathrm{~min}$ and vitrification solution (VS) for 5 min [ES composition: Dulbecco's phosphatebuffered saline (DPBS) supplemented with $20 \%(\mathrm{v} / \mathrm{v})$ fetal bovine serum (FBS; Sigma, USA), $7.5 \%(\mathrm{v} / \mathrm{v})$ dimethylsulfoxide (DMSO; Sigma, USA) and 7.5\% (v/v) ethylene glycol (EG; Sigma, USA); VS composition: DPBS containing 20\% FBS, 20\% EG, 20\% DMSO and 0.5 $\mathrm{M}$ sucrose (Sigma, USA)]. The ovaries were placed on gauze to remove the vitrification solution. Then, we placed the ovaries in a $1.5-\mathrm{ml}$ cryovial (Corning, Mexico) and placed the cryovial in liquid nitrogen (LN2).

A week after vitrification, the vials were rapidly removed from LN2, incubated at room temperature for 10-20 s and warmed through stepwise dilution of sucrose at concentrations of $1.0,0.5,0.25$, and $0 \mathrm{M}$ in D-PBS medium supplemented with $20 \%$ FBS for 5 min each. In the fresh $(n=6)$ and vitrification-warmed control groups, the OT was immediately fixed in $4 \%$ paraformaldehyde after ovariectomy or freezing and thawing, respectively.

\section{Experiment I: evaluation of the best concentration of resveratrol}

Autotransplantation was performed as described in Lee et al. [28]. After analgesia was provided to the mice, the dorsal fur was shaved, and the abdominal skin was sterilized with $70 \%(\mathrm{v} / \mathrm{v})$ alcohol. A 1-cm incision was made on the skin, and both kidneys were externalized through the incision site. A small hole was created, vitrificationwarmed ovaries from a mouse were placed inside the bilateral kidney capsules, and the incision and skin were closed and sutured. The mice were randomly divided into four groups according to the treatment: saline $(n=$ 18); $5 \mathrm{mg} / \mathrm{kg}$ resveratrol $(\mathrm{n}=18) ; 15 \mathrm{mg} / \mathrm{kg}$ resveratrol $(n=18)$ and $45 \mathrm{mg} / \mathrm{mg}$ resveratrol $(\mathrm{n}=18)$. Substances were given orally for one week. Resveratrol was insoluble in water and dissolved in $1 \%$ sodium carboxymethyl cellulose solution. Sodium carboxymethyl cellulose was diluted in saline. $1 \mathrm{ml}$ of different concentration of resveratrol was given by oral gavage daily. The same volume of saline was given by oral gavage in the sham control group by using the same scheme described earlier. Ovarian grafts were retrieved 3,7 and 21 days after transplantation to assess the morphology and graft survival. Six mice per group were used for histology and serum $E_{2}$ and $\mathrm{FSH}$ analyses to select the most effective dose of resveratrol. Based on previous studies [29], we selected days 3, 7 and 21 for evaluation of ovarian follicle development and function. After mice were placed in airtight containers and anesthetized to death with an overdose of isoflurane.

\section{Follicle classification and morphological analysis}

OTs were fixed in $4 \%$ paraformaldehyde and embedded in paraffin. The specimens were cut into $5-\mu \mathrm{m}$ sections for morphological analysis or immunohistochemical staining. The sections were collected and stained with hematoxylin and eosin (H\&E, Weiwo, China). Ovarian follicles were classified according to Lundy et al. [30] for developmental stage. The stages were defined as follows: 
Primordial follicles: a single layer of flattened granulosa;

Primary follicles: a complete single layer of granulosa cells, one or more of which is cuboidal;

Secondary follicles: two or more layers of cuboidal granulosa cells with no antrum; Antral follicles: multiple layers of cuboidal granulosa cells with the antrum present.

Gandolfi's [6] criteria were used for morphological integrity.

Primordial/primary follicle: G1, spherical with an even distribution of granulosa cells; G2, granulosa cells pulled away from the edge of the follicle but with spherical oocytes; G3, pyknotic nuclei, misshapen oocytes or vacuolation; Secondary/antral follicle: G1, intact spherical follicle with evenly distributed granulosa and theca cells, a small space and spherical oocytes; G2, intact theca cells, disrupted granulosa cells and spherical oocytes; G3, disruption and loss of granulosa and theca cells, pyknotic nuclei and missing oocytes.

\section{Enzyme-linked immunosorbent assays for $\mathrm{E}_{2}$ and $\mathrm{FSH}$}

Whole blood was collected from OT-transplanted mice 3,7 and 21 days after transplantation. After centrifugation (3000 g for $5 \mathrm{~min}$ ), an enzyme-linked immunosorbent assay (ELISA) was performed to analyze $\mathrm{E}_{2}$ and FSH (Cusabio, China) in sera. A microplate reader capable of measuring absorbance at $450 \mathrm{~nm}$ was used, and the concentrations of serum $E_{2}$ and FSH were calculated. The intra- and inter assay precision coefficients of variation were $<15 \%$. The minimum detectable dose of mouse $E_{2}$ is typically less than $40 \mathrm{pg} / \mathrm{ml}$, and FSH is less than 2.5 $\mathrm{mIU} / \mathrm{ml}$. A standard curve was created by reducing the data using computer software capable of generating a four-parameter logistic curve fit. $\mathrm{E}_{2}$ and FSH levels were calculated by the professional software 'Curve Expert 1.4' (Curve Expert, USA).

\section{Experiment II: further evaluation of the effects of resveratrol and exploration of the mechanisms}

From follicle histological and endocrine function, we found that $45 \mathrm{mg} / \mathrm{kg}$ resveratrol was beneficial for the grafted ovary tissue. The mice were randomly divided into two groups: saline $(n=46)$ and $45 \mathrm{mg} / \mathrm{kg}$ resveratrol $(n=46)$.

\section{Apoptosis analysis}

We observed follicle depletion in the early days of transplantation (day3 and day7). Therefore, we analyzed apoptosis on day 3 and day 7 between the two groups.

After deparaffinization and rehydration, sections were washed in PBS and treated with proteinase $\mathrm{K}(10 \mathrm{mg} / \mathrm{ml}$, $37^{\circ} \mathrm{C}, 30 \mathrm{~min}$ ) in $10 \mathrm{mM}$ Tris- $\mathrm{HCl}$ buffer. Then the sections were rinsed twice with $\mathrm{PBS}$, they were incubated with $50 \mu \mathrm{l}$ of terminal deoxynucleotidyl transferasemediated dUTP nick-end labeling (TUNEL) reaction mixture for $1 \mathrm{~h}$ at $37^{\circ} \mathrm{C}$ in a humidified chamber in the dark and rinsed with PBS twice. Negative controls were prepared by treatment with $1500 \mathrm{U} / \mathrm{ml}$ DNase I (Roche Applied Science) in $50 \mathrm{mM}$ Tris- $\mathrm{HCl}$ (pH 7.5, including $1 \mathrm{mg} / \mathrm{ml}$ bovine serum albumin) for $10 \mathrm{~min}$ at room temperature to induce DNA strand breaks prior to the labeling procedures. Some OT specimens were used as negative controls by substituting terminal deoxynucleotidyl transferase with distilled water in the reaction mixture following the protocol. Mounting medium with 4', 6-diamidino-2-phenylindole (DAPI) was added (Vector Laboratories, USA), and the samples were examined under an inverted Zeiss AX10 microscope. An untreated TUNEL reaction mixture was used as a negative control, and a slide treated with $100 \mathrm{U} / \mathrm{ml}$ of DNase I was used as a positive control.

Six tissue sections from each group were obtained for analysis $(n=24)$. TUNEL-positive cells produced green fluorescence at excitation wavelengths. When $30 \%$ of the cells in one follicle were TUNEL positive, the follicle was regarded as apoptotic. DAPI produces fluorescence when bound to DNA.

\section{Immunohistochemistry}

Ovaries were collected from OT-transplanted mice at 3 and 7 days. To explore the molecular mechanism of resveratrol, we tested relevant markers on the grafted ovary through immunohistochemical examination to validate the selected pathways. Sections were incubated for $1 \mathrm{~h}$ with primary antibodies against MDA (StressMarp, SMC-515, 1:800), SOD2 (Huabio, ET1701-54, 1:50), NF-kb (Huabio, R1309-9, 1:50), IL-6 (Huabio, R1412-2, 1:50), and SIRT1 (Huabio, ER1308-11, 1:50) at RT in a humid chamber, washed, and treated with EnVision goat anti-mouse IgG (Fuzhou Maixin, KIT-5006). A peroxidase substrate kit (SGK347011, Shanghai Gene) was used as a chromogen, and hematoxylin was used as a counterstain. Finally, six tissue sections from each group were obtained for analysis. The slides were examined under an inverted Zeiss AX10 microscope (Carl Zeiss, Germany). Brown coloring of the cytoplasm/nucleus of stromal cells, granulosa cells, or oocytes was defined as positive staining (any other coloring was considered negative staining).

\section{Gene expression analysis with real-time polymerase chain reaction}

Ovaries were collected from OT-transplanted mice at 3 and 7 days, 8 mice per group were used for real-time quantitative PCR analysis $(n=32)$, and total RNA was isolated by using TRIzol (Invitrogen, Carlsbad, CA, USA). cDNA synthesis was performed with 
PrimeScriptTM RT Master Mix (Perfect Real Time). PCR analyses were performed with TB Green ${ }^{\text {Tx }}$ Premix Ex Taq ${ }^{\text {Ti }}$ II (TliRNaseH Plus) (TaKaRa, Code No. RR820A). The final PCR volume was $10 \mu \mathrm{l}$. The primer sequences used for real-time quantitative PCR are listed in Table 2.

The cycling conditions for the PCR were as follows: $95^{\circ} \mathrm{C}$ for $30 \mathrm{~s}$ and $95^{\circ} \mathrm{C}$ for $5 \mathrm{~s}$ for 40 cycles and $60^{\circ} \mathrm{C}$ for $30 \mathrm{~s}$ for 40 cycles. Gene expression levels were evaluated using the delta-delta CT method and standardized to the GAPDH amplification levels.

\section{Western blot analysis}

Ovaries were harvested on days 3 and 7 after transplantation and rapidly frozen in LN2, and six mice per group were used for western blot analysis $(n=24)$. Each ovary tissue sample was homogenized in ice-cold homogenization buffer containing protease inhibitors. Tissue homogenates were centrifuged at $5000 \times \mathrm{g}$ for $5 \mathrm{~min}$ at $4{ }^{\circ} \mathrm{C}$, and the supernatants were collected. The Bradford method was used for protein quantification. Proteins solubilized in $4 \times$ Laemmli sample buffer were subjected to SDS-PAGE and then transferred onto nitrocellulose membranes. After the membranes were blocked with T-TBS for $1 \mathrm{~h}$ at room temperature, they were probed with various primary antibodies overnight at $4{ }^{\circ} \mathrm{C}$ [MDA (StressMarp, SMC-515, 1:1000), SOD2 (Huabio, ET1701-54, 1:1000), NF-кB (Huabio, R1309-9, 1:500), IL-6 (Huabio, R1412-2, 1:1000) and SIRT1 (Huabio, ER130811, 1:1000)]. After the membranes were washed with T-TBS, they were incubated with the corresponding secondary antibodies conjugated with horseradish peroxide for $1 \mathrm{~h}$. Detection was conducted with an ECL kit (Millipore). Protein bands were scanned and analyzed with Quantity One Image Analysis Software (Bio-Rad, Hercules, CA, USA).

\section{Oocyte retrieval, in vitro maturation, IVF and in vitro} culture

Twenty-one days after OT transplantation, 12 transplanted mice (6 mice/group) were hyperstimulated via intraperitoneal injection of $10 \mathrm{IU}$ of pregnant mare's serum gonadotrophin. After $48 \mathrm{~h}$, cumulus-oocyte complexes (COCs) were obtained by ovary puncture and then matured in vitro in M16 medium (Sigma, USA) at $37^{\circ} \mathrm{C}$ for $14 \mathrm{~h}$. After in vitro maturation (IVM), nuclear maturation was examined. Extrusion of the first polar body was the maturation criterion and was scored under an inverted microscope (50x magnification). For sperm collection, mice were executed by cervical dislocation, and the abdominal skin was sterilized with $70 \%(\mathrm{v} / \mathrm{v})$ alcohol. A $1.5-\mathrm{cm}$ incision was made in midline abdominal wall, and the reproductive system was exposed. The head and tail of the epididymis and part of the vas deferens were cut together and then placed in culture medium in a glass dish. Fat tissue was removed under a microscope, and sperm inside the head of the epididymis and vas deferens were extruded to the cauda with ophthalmic forceps. Then, the heads of the epididymis and vas deferens were cut off. Sperm were released from the cauda of the epididymis and incubated for $1 \mathrm{~h}$. The capacitation fluid containing sperm was absorbed and centrifuged at $1000 \mathrm{rpm}$ for $4 \mathrm{~min}$ to collect sperm.

For fertilization, mature metaphase II (MII) oocytes were inseminated with sperm for $5 \mathrm{~h}$, and the fertilized embryos obtained were washed with M16 medium and incubated at $37^{\circ} \mathrm{C}$ for $24 \mathrm{~h}$. Then, the fertilized embryos were placed in M16 medium (Global Media, LifeGlobal, Belgium) for further development. Fertilization was assessed by the formation of two cells $24 \mathrm{~h}$ after insemination. The cleavage and blastocyst rates were calculated.

Table 2 The primer sequences used for real-time quantitative PCR

\begin{tabular}{|c|c|c|c|}
\hline Genes & Primers & Sequences $\left(5^{\prime}-3^{\prime}\right)$ & Expected size (bp) \\
\hline \multirow[t]{2}{*}{ SIRT1 } & Sense & GCTGACGACTTCGACGACG & 101 \\
\hline & Antisense & TCGGTCAACAGGAGGTTGTCT & \\
\hline \multirow[t]{2}{*}{ MDA } & Sense & AGATGCCTTCAAACGGAGGAA & 169 \\
\hline & Antisense & CAAGCTCAGAGTGGTGTGTCG & \\
\hline \multirow[t]{2}{*}{ SOD } & Sense & AACCAGTTGTGTTGTCAGGAC & 139 \\
\hline & Antisense & CCACCATGTTTCTTAGAGTGAGG & \\
\hline \multirow[t]{2}{*}{ IL-6 } & Sense & CCAAGAGGTGAGTGCTTCCC & 117 \\
\hline & Antisense & СTGTTGTTCAGACTCTCTCCCT & \\
\hline \multirow[t]{2}{*}{ NF-kB } & Sense & ATGGCAGACGATGATCCCTAC & 111 \\
\hline & Antisense & TGTTGACAGTGGTATTTCTGGTG & \\
\hline \multirow[t]{2}{*}{ GAPDH } & Sense & AGGTCGGTGTGAACGGATTTG & 123 \\
\hline & Antisense & TGTAGACCATGTAGTTGAGGTCA & \\
\hline
\end{tabular}




\section{Statistical analysis}

The Statistical Package for the Social Sciences version 24.0 software (SPSS, Inc., USA) and GraphPad Prism 5.0 (GraphPad Software, USA) were used for statistical analysis. Unless otherwise indicated, the results are shown as the mean \pm SD. Data were analyzed by Student's t-test (TUNEL, MII oocytes, fertilization, cleavage and blastocyst formation), one-way analysis of variance (serum FSH and $\mathrm{E}_{2}$, qRT-PCR, and western blot), and $\chi^{2}$ tests (the proportions of G1 follicles). $P<0.05$ was considered significant.

\section{Results}

\section{Evaluation of the best concentration of resveratrol (experiment I)}

\section{Follicle classification and morphological analysis}

The frozen-thawed OT appeared well preserved; $75 \%$ of the follicles were primordial, primary and secondary; and the stromal cells showed an intact shape. However, the proportions of Grade 1 antral follicles decreased, and the differences were highly significant (fresh: 67.6\%; cryopreservation-warmed: $40 \%)$. On morphological analysis, the antral follicles showed atresia, and the surrounding granular cells were loose. On day 3 after OT transplantation, the transplanted ovaries could be easily detached from the kidneys, although many red blood cells were present around the kidney capsule (Supplementary, Fig. S). However, adhesion between the grafts and the kidneys was enhanced in a time-dependent manner. On day 21 after transplantation, the blood vessels in the transplanted OT increased substantially. The quantity and quality of ovarian follicles at all stages deteriorated after transplantation compared with those of fresh OT and cryopreservation-warmed OT, and oocyte shrinkage and a collapsed follicular structure were observed (Fig. 1a). The proportion of Grade 1 primordial follicles significantly increased in the $45 \mathrm{mg} / \mathrm{kg}$ resveratrol group compared with the saline and other resveratrol-treated groups on days 3 and 7, which was consistent with observations of antral follicles (Fig. 1b). Moreover, on day 21, resveratrol-treated $(45 \mathrm{mg} / \mathrm{kg})$ ovarian grafts showed increased G1 follicle ratios in the developmental stages (primary and antral follicles) compared with grafts in the other three groups. Figure 1c shows the mean number of total G1 follicles in each stage per section before and after cryopreservation and transplantation in the four different groups on days 3,7 and 21. A 50\% reduction in the mean G1 ovarian follicle number was observed with autotransplantation in the four transplantation groups compared with the fresh control and vitrification-warmed control groups. However, the $45 \mathrm{mg} / \mathrm{kg}$ resveratrol group showed a significantly higher number of $\mathrm{G} 1$ follicles than the $5 \mathrm{mg} / \mathrm{kg}$ group at 7 days and the saline and $5 \mathrm{mg} / \mathrm{kg}$ groups at 21 days (Fig. 1c).

\section{Serum $\mathrm{E}_{2}$ and $\mathrm{FSH}$ levels}

The serum concentrations of FSH and $\mathrm{E}_{2}$ at 3 and 7 days after transplantation were not different between the two groups (Fig. 2). Furthermore, we found that FSH increased on day 7 after transplantation and was higher than that on day 3 , although no difference was found between the two groups. However, on day 21 after transplantation, we found that the serum FSH level was significantly decreased in the resveratrol group compared with the saline groups $(P<0.05)$. The serum $\mathrm{E}_{2}$ level was significantly increased in the resveratrol group, and the $E_{2}$ level was highest in this group; these changes were significant.

\section{The effects of resveratrol and the mechanisms on autotransplantation of frozen-thawed mouse ovarian tissue (experiment II) \\ Apoptosis analysis}

TUNEL-positive follicles were detected in the two groups on days 3 and 7 (Fig. 3). Three days after transplantation, the two groups showed an approximately $30 \%$ apoptotic follicle ratio. The apoptotic follicle ratio decreased in the 7 -day group, and $13 \%$ of positive staining signals were detected in the resveratrol group. The apoptotic follicle ratio was significantly decreased in the $45 \mathrm{mg} / \mathrm{kg}$ resveratrol group compared with the saline group.

\section{Immunohistochemistry, gene expression and western blot analysis}

Figure 4 shows a representative immunohistochemical image of MDA-, SOD2-, NF-kB-, IL-6-, and SIRT1positive areas in the ovary at 3 and 7 days after transplantation. MDA is a marker of oxidative stress and is mainly expressed in the nuclei of oocytes and other various cells in OT. SOD2, a subtype of SOD, is mainly expressed in the oocyte cytoplasm of various cells in OT. NF- $\mathrm{BB}$ is a nuclear transcription factor expressed in the oocyte nucleus, granule cells and basal interstitial cells. IL-6 is widely expressed in the nuclei and cytoplasm of various cells in the ovary. SIRT1 is mainly expressed in the oocyte nucleus, granule cells and basal interstitial cells. Real-time PCR demonstrated that the levels of MDA and NF-kB were significantly lower in the $45 \mathrm{mg} / \mathrm{kg}$ resveratrol group than in the saline group at day 3 (Fig. 5). IL-6, a proinflammatory cytokine, was lower in the $45 \mathrm{mg} / \mathrm{kg}$ than that in the saline group on day 7. Furthermore, a significant increase in SOD levels was observed on days 3 and 7 compared in the $45 \mathrm{mg} / \mathrm{kg}$ with those in the saline group. However, no difference in SIRT 1 was observed between auto-transplanted OT treated with $45 \mathrm{mg} / \mathrm{kg}$ resveratrol and $\mathrm{OT}$ in the saline group.

Western blot analysis revealed that the levels of SOD2 and SIRT1 were significantly higher in the resveratrol 


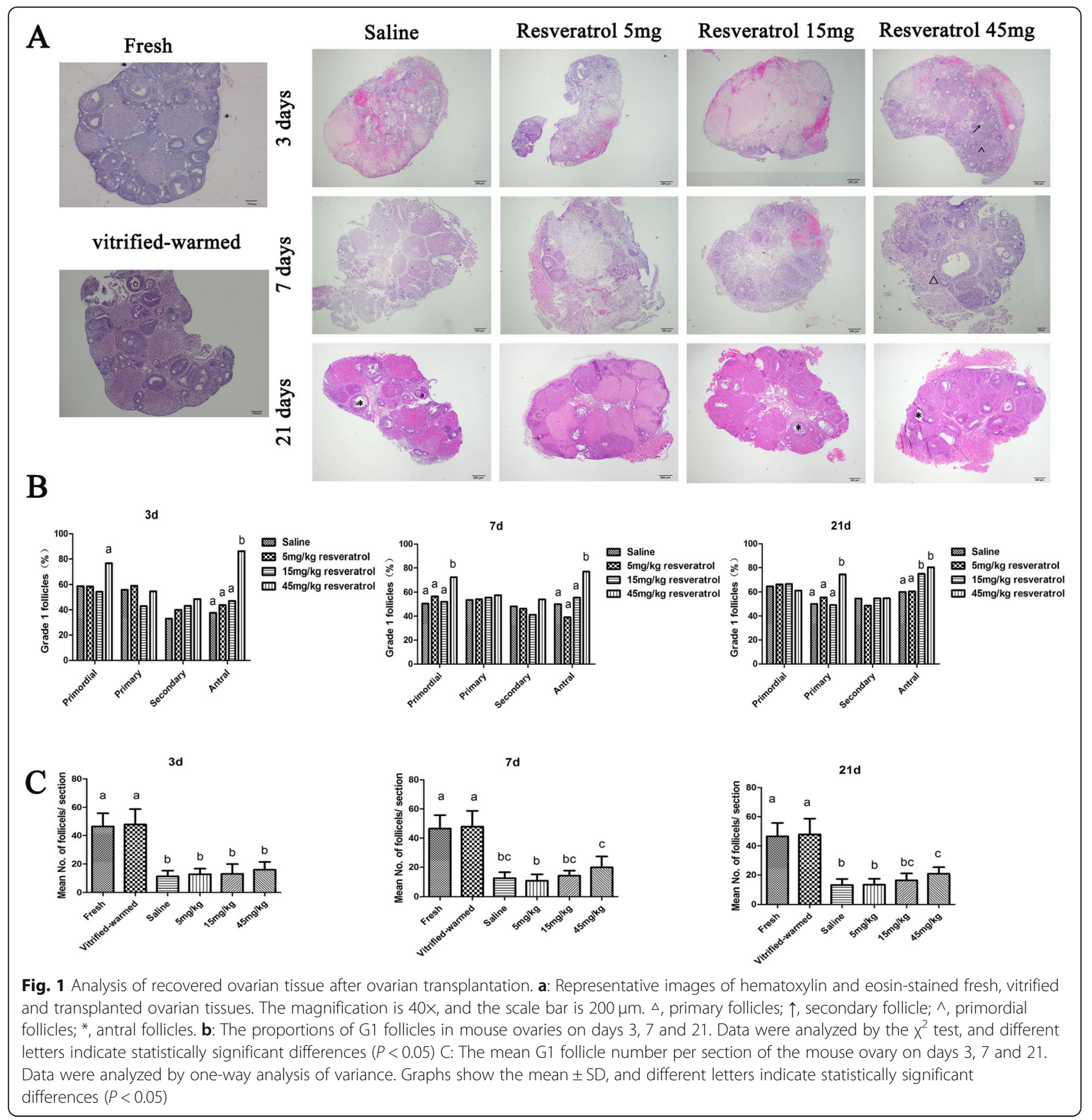

group than in the saline group on day 7 (Fig. 6). Furthermore, MDA and NF- $\mathrm{BB}$ levels were lower in the resveratrol group than those in the saline group on day 3 . Likewise, IL-6 was lower in the resveratrol group than that in the saline groups on day 7 . These results are basically consistent with the qRT-PCR results.

\section{IVM, IVF, and in vitro embryonic development derived from autotransplanted ovaries}

Figure 7 and Table 3 show data for the embryonic development of oocytes retrieved from OT grafts 21 days after transplantation. The mean number of retrieved oocytes and fertilization and cleavage were significantly increased in the resveratrol group compared with the saline group $(P<0.05)$ but not the MII group. Although blastocysts were cultured after insemination in the two groups, no significant difference was noted. The number of blastocysts was insufficient, and most embryos eventually degenerated.

\section{Discussion}

Hypoxia and ischemia before neovascularization are major concerns in OT transplantation because they 
$\mathrm{E}_{2}$

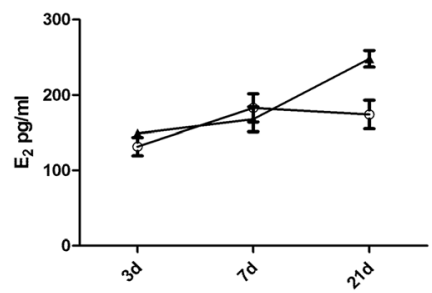

FSH

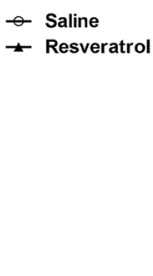

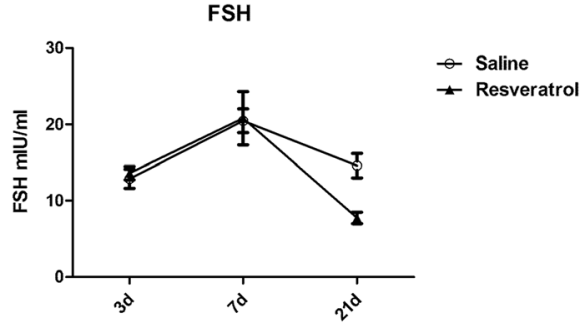

Fig. 2 Serum $E_{2}$ and FSH levels in autotransplanted mice. Serum $E_{2}$ and FSH levels were detected by enzyme-linked immunosorbent assay on days 3, 7 and 21. Data were analyzed by analysis of variance. Graphs show the mean \pm SD, and different letters indicate statistically significant differences $(P<0.05)$

cause extensive follicle loss [31]. Increasing the lifespan and quality of grafts, which may result in improved pregnancy outcomes for cancer patients, has been a major challenge in recent years [14]. A microdialysis probe inserted in grafted OT showed long progression from anaerobic to aerobic metabolism and a protracted period of ROS generation [32]. Oxidative stress was observed relatively late, after the most critical period of follicle loss, and lasted until the tissue vasculature stabilized [32].

In the present study, our results show that the proportion of G1 follicles was significantly higher, and only $13 \%$ of TUNEL positive staining signals were detected in the $45 \mathrm{mg} / \mathrm{kg}$ resveratrol group; additionally, in the same group, recovered at day 21. IHC, PCR and WB showed that SOD2 and SIRT1 were significantly higher, while MDA and NF- $\kappa B$ were lower than those in the saline group on day 3 , and IL-6 was lower than that in the saline group on day 7 . Based on the results, resveratrol was believed to prevent ovarian follicle damage and restore ovarian function promptly. In addition, we speculated that signaling pathway involved oxidative stress and anti-inflammatory could play an important role after transplantation.

A substantial reduction in the percentage of morphologically normal antral follicles was noted. Because antral follicles are very large and surrounded by multiple layers of cuboidal granulosa cells, they could not tolerate the freezing damage and maintain their structural integrity during vitrification [11]. Nevertheless, preantral follicles can maintain their follicular structure and survive the transplantation procedure [10,33]. Vitrification is a kind of technology that is easy to perform for the simple and quick preservation of ovaries. Moreover, the conventional slow-freezing is commonly regarded to inevitably introduce 'two factors' injuries to the cells, i.e. the injuries caused by intra-cellular ice formation and the elevated concentration of the residual solution [27, 34]. Vitrification has been shown to overcome these problems. Therefore, vitrification is an effective method for

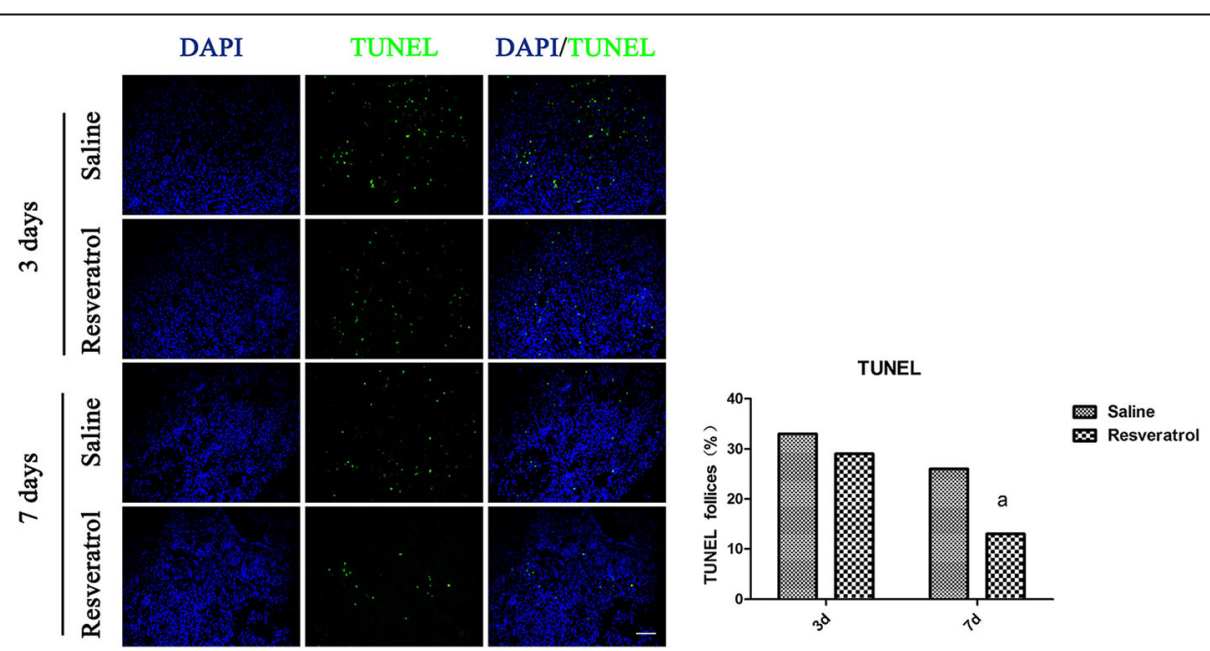

Fig. 3 Terminal deoxynucleotide transferase-mediated dUTP nick-end labeling staining showing apoptotic follicles (green, TUNEL) and cell nuclei (blue, DAPI) between the two groups on days 3 and 7 after ovarian transplantation. The letters indicate statistically significant differences $(P<$ $0.05)$ in the apoptotic follicle ratio between the two groups on day 7 after ovarian transplantation. The magnification is 200x, and the scale bar is $50 \mu \mathrm{m}$ 


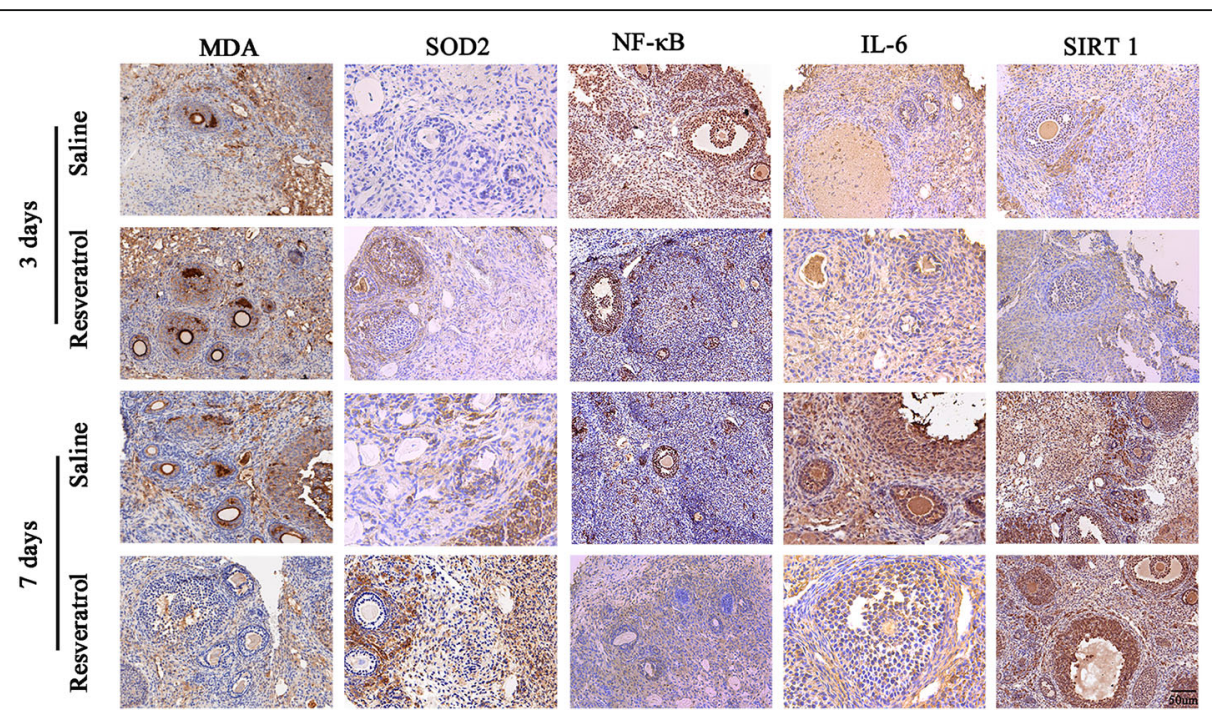

Fig. 4 Immunohistochemical staining of ovarian tissue (OT) for MDA, SOD2, NF-KB, LL-6 and SIRT1. The magnification is 200x, and the scale bar is $50 \mu \mathrm{m}$
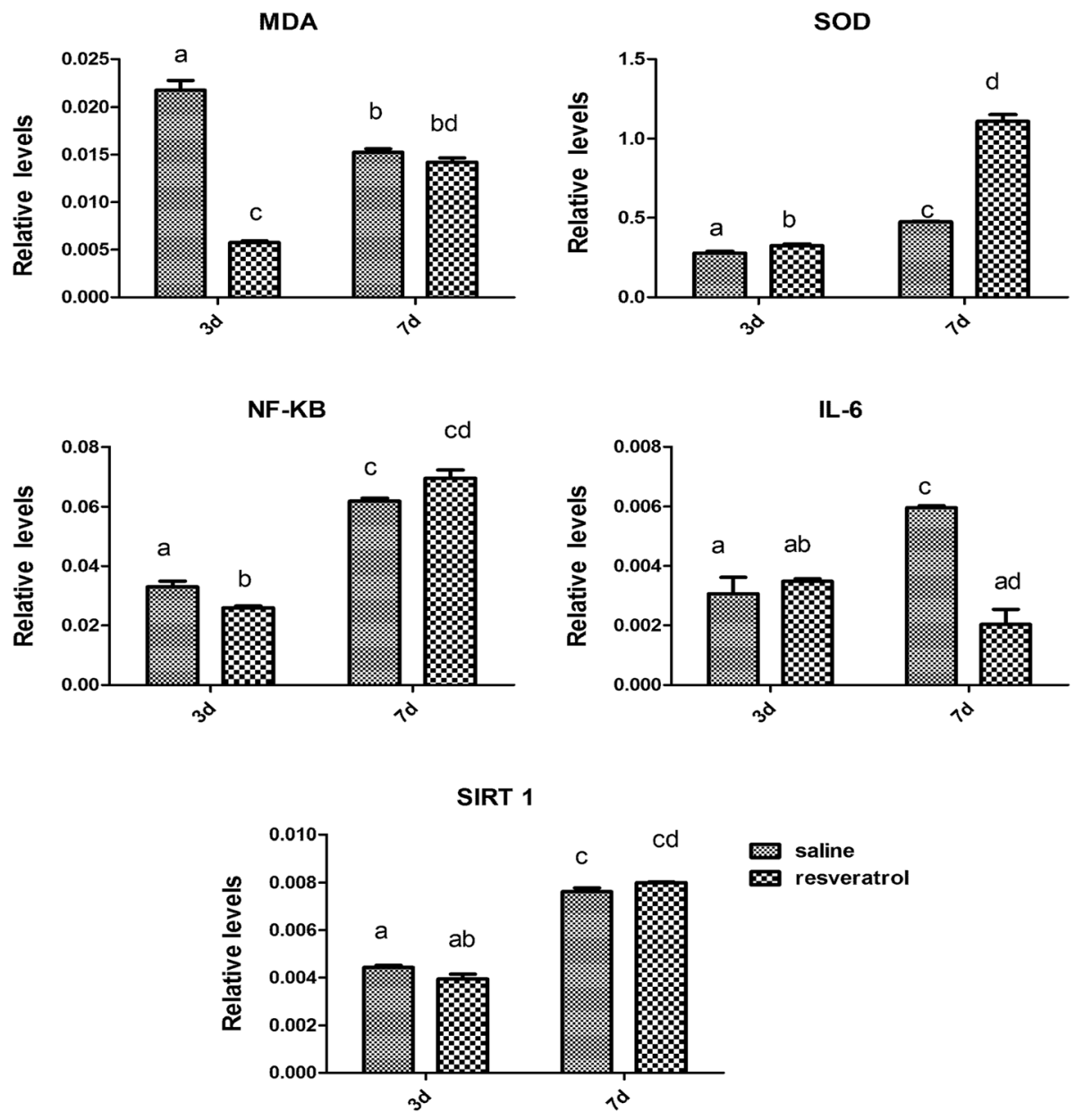

Fig. 5 The relative levels of MDA, SOD, NF-KB, IL-6, and SIRT 1 mRNA by real-time PCR in ovarian tissue 3 days and 7 days after auto-transplantation. Data represent the mean \pm SD. The different superscript letters represent significant differences between the two groups at different times 


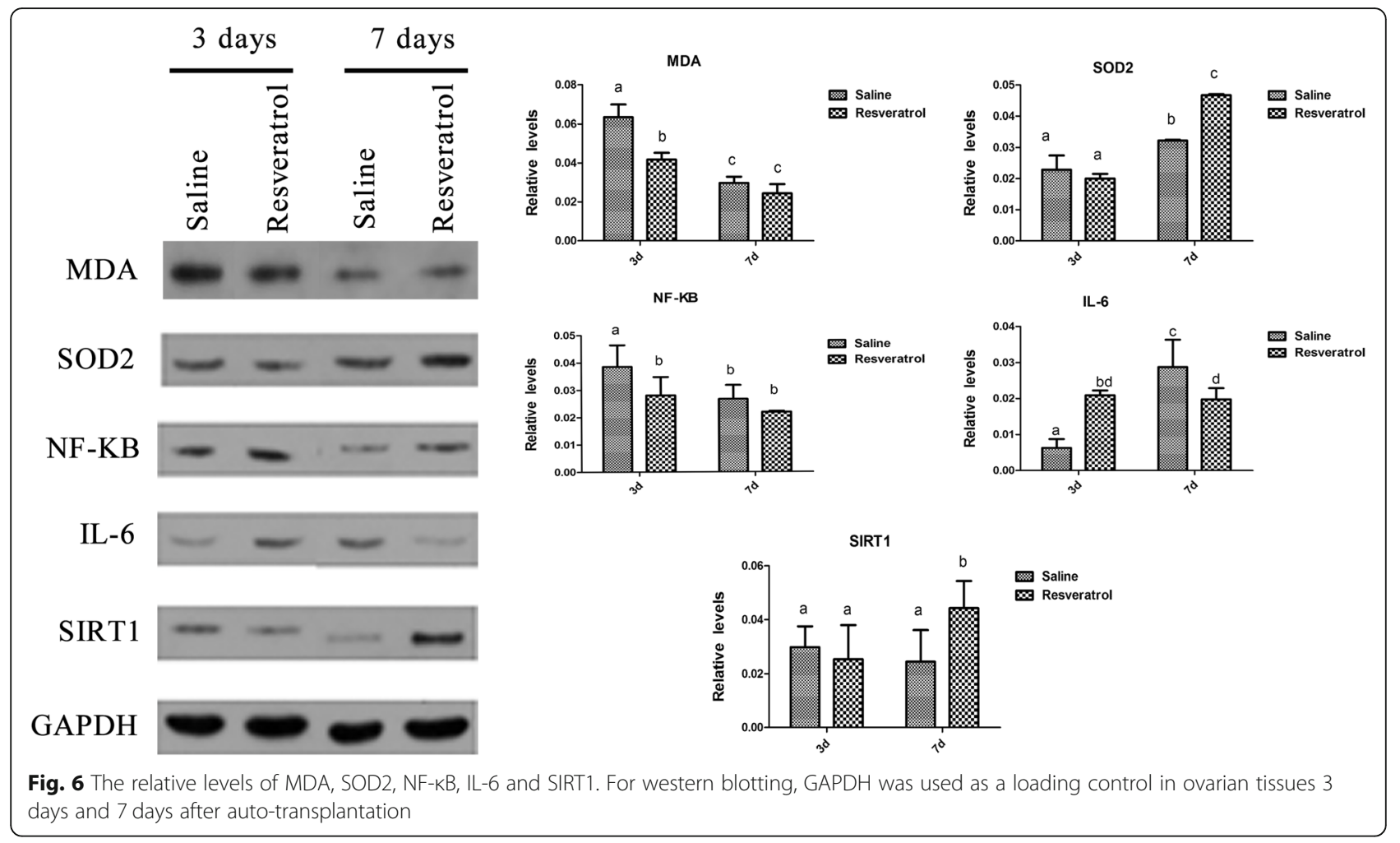

fertility preservation as previous research has shown that antral follicles damaged in cryopreservation have no effect on transplantation. Post-transplantation damage is the main cause of ovarian injury during cryopreservation and transplantation [35].

Previous reports revealed that granulosa cells and oocytes, particularly in developing follicles, undergo apoptosis as a result of ischemia-reperfusion injury induced by free radicals and lipid peroxidation on the first day of transplantation [36]. This process can lead to degeneration and atresia of follicles and disruption of folliculogenesis and oogenesis. In this study, we tested different concentrations of resveratrol to demonstrate its effect $(5 \mathrm{mg} / \mathrm{kg}, 15 \mathrm{mg} / \mathrm{kg}$ and $45 \mathrm{mg} / \mathrm{kg}$ ) and found that,

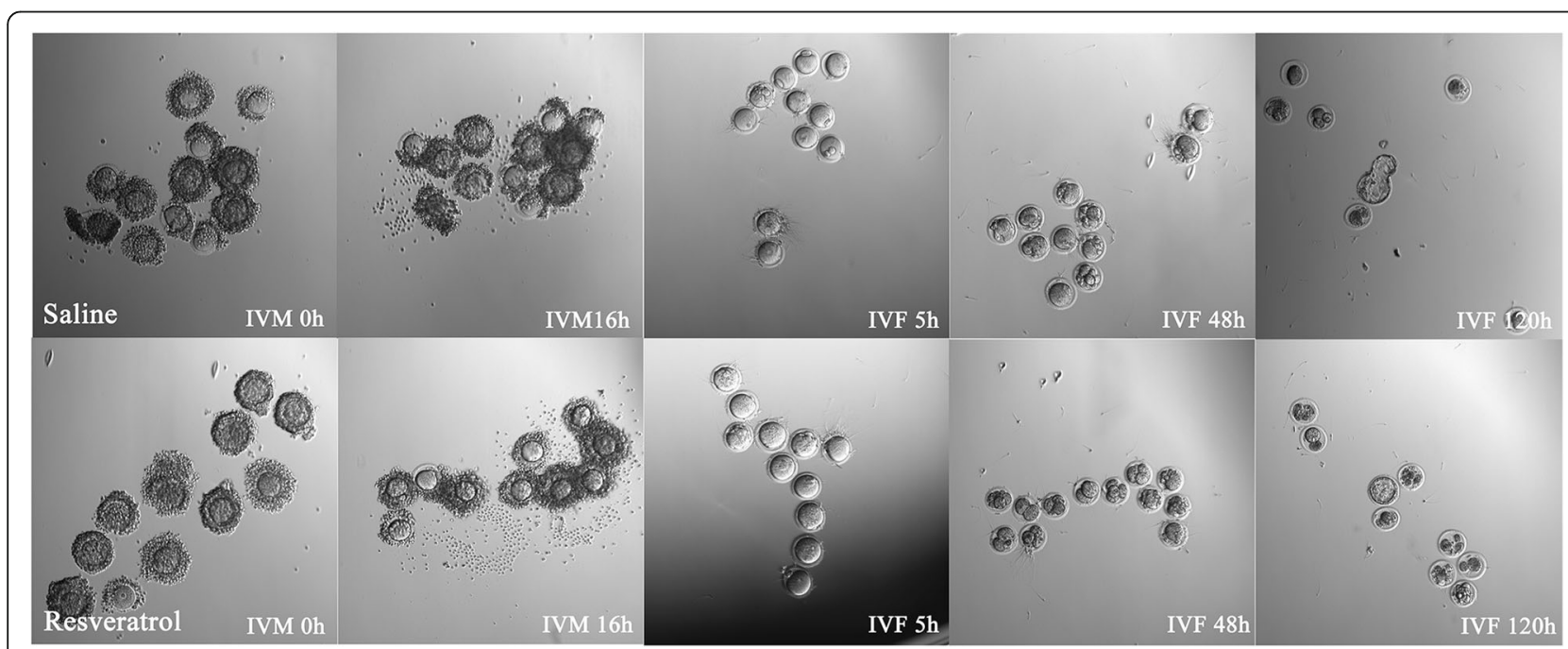

Fig. 7 The embryonic development of mouse oocytes retrieved from ovarian tissue grafts 21 days after transplantation. (IVM and IVF oocytes; the magnification was $\times 100$ ) 
Table 3 The embryonic development of mouse oocytes retrieved from ovarian tissue grafts 21 days after transplantation. MII, Metaphase II (Mean \pm SD)

\begin{tabular}{llllll}
\hline Group & $\begin{array}{l}\text { No. of retrieved } \\
\text { oocytes }\end{array}$ & $\begin{array}{l}\text { No. of MII } \\
\text { oocytes }\end{array}$ & $\begin{array}{l}\text { No. of fertilized } \\
\text { oocytes }\end{array}$ & $\begin{array}{l}\text { No. of cleaved } \\
\text { oocytes }\end{array}$ & $\begin{array}{l}\text { No. of } \\
\text { blastocysts }\end{array}$ \\
\hline Saline (from 8 ovaries) & $14.88 \pm 2.75$ & $9.63 \pm 2.13$ & $5.88 \pm 1.81$ & $4.50 \pm 1.51$ & $0.5 \pm 0.76$ \\
$\begin{array}{l}\text { Resveratrol (from 8 } \\
\text { ovaries) }\end{array}$ & $20.63 \pm 5.07$ & $11.13 \pm 3.40$ & $9.88 \pm 3.48$ & $8.50 \pm 3.02$ & $0.5 \pm 0.54$ \\
t & -2.82 & -1.06 & -2.89 & -3.35 & 0.00 \\
p & 0.01 & 0.31 & 0.01 & 0.01 & 1.00 \\
\hline
\end{tabular}

$t$ Student's t-test, $p$ value

In the $45 \mathrm{mg} / \mathrm{kg}$ resveratrol group, the $\mathrm{G} 1$ rate of primordial follicles on day 3 was significantly higher than that in the saline group, and the same results were observed at 7 days. Based on these results, we used this concentration for Experiment II. Moreover, the ratio of TUNELpositive follicles decreased in the resveratrol group 7 days after transplantation. The primordial follicles shifted to secondary follicles and antral follicle on day 21 after transplantation. This trend suggests that resveratrol may improve the quality of follicles by reducing follicle apoptosis after transplantation. The mean number of follicles in grafted OT decreased compared with that in cryopreservation-warmed OT $(24.25 \pm 6.51)$.

FSH and $E_{2}$ levels are widely used to evaluate ovarian reserve. The FSH levels on day 3 were substantially higher than the normal range (lower than $10 \mathrm{ng} / \mathrm{ml}$ ) due to the absence of negative feedback from the ovary during the period between ovariectomy and OT survival [37]. However, after OT ischemia-reperfusion and survival, ovarian function was evaluated by detecting FSH and $E_{2}$ levels, which recovered on day 21 , indicating that the transplanted OTs functionally recovered after 21 days in the mouse model. Restoration of ovarian function post-transplantation was also indicated by the presence of antral follicles and corpus luteum in the OT.

To our knowledge, grafted OT undergoes a protracted period of ROS generation, which can cause oocyte, granulosa cell and membrane lipid damage or apoptosis [32]. Resveratrol is a strong antioxidant, and our results revealed that resveratrol can improve the quality of ovarian tissue after autotransplantation. To explore the mechanisms of resveratrol, we examined several factors related to oxidative stress (SIRT1, MDA and SOD2) and inflammation (NF-kB and IL-6) using immunohistochemistry. We found that these five specific factors were all observed in different cell of the grafts by IHC.

Immunohistochemistry, Quantitative real-time PCR and western blots revealed the potential mechanisms of resveratrol in our study. Resveratrol could decrease the level of MDA by increasing SOD to reduce oxidative stress [38]. Another explanation for this mechanism is that resveratrol inhibits NF- $\mathrm{kB}$ and interfere with NF- $\mathrm{kB}$ signal transduction on day 3 and results in reduced release of proinflammatory cytokines, such as IL-6, 7 days after transplantation [39]. NF- $\kappa B$ [40] is a nuclear transcription factor that mediates intracellular signal transduction. SIRT1 regulates the activation or inhibition of multiple target proteins. Both in vivo and in vitro, the antioxidant and anti-inflammatory actions of resveratrol have been reported to be mediated by SIRT1 activation [41]. However, no significant differences were observed in the relative level of SIRT1 as shown by qRT-PCR, whereas a significant increase was observed at the protein level. SIRT1 is a highly conserved NAD + -dependent deacetylase that plays a cellular protective role by deacetylating substrate proteins to resist various stressors and repair gene mutations [42]. We speculated that after transcription, the mRNA must pass through the nuclear membrane to be translated into a protein [42]. Resveratrol might promote the translation of SIRT1.

In the present study, we found that antral follicles could be observed 21 days after transplantation, and that the rate of oocyte induction by puncture was significantly lower than that of normal ovaries from controlled ovarian hyperstimulation $(\mathrm{COH})$ [43]. A significant increase in the number of MII follicles in the resveratrol group compared with the saline control group was observed. After IVF, the fertilization and cleavage rates in the resveratrol group were higher than those in the saline group. Resveratrol increased the cleavage rate, but no difference in the number of blastocysts was found between the two groups. Due to the small number of cultured blastocysts, further testing the quality of the embryos was difficult, and most embryos eventually degenerated. In vivo transplantation may be an ideal method, and more studies are needed in the future.

\section{Conclusion}

This study demonstrated that resveratrol can improve the efficacy of autotransplantation of frozen-thawed mouse OT through anti-inflammatory and antioxidative mechanisms, which is consistent with the increased follicle survival rate and reduced follicle apoptosis. However, this study did not assess metabolic parameters. We tested the effect of resveratrol on grafted tissue, which is a preliminary experiment; therefore, further studies are necessary to elucidate the mechanisms of resveratrol in 
minimizing ischemia-reperfusion injury in the ovaries of other domestic animals and in humans.

\section{Abbreviations}

OT: Ovarian tissue; OTCT: Ovarian tissue cryopreservation and transplantation; ROS: Reactive oxygen species; IP: Intraperitoneal; ES: Equilibration solution; VS: Vitrification solution; DPBS: Dulbecco's phosphate-buffered saline; TUNEL: Terminal deoxynucleotidyl transferase-mediated dUTP nick-end labeling; DAPI: 4',6-diamidino-2-phenylindole; ELISA: Enzyme-linked immunosorbent assay; PCR: Polymerase chain reaction; RBCs: Red blood cells

\section{Supplementary Information}

The online version contains supplementary material available at https://doi. org/10.1186/s12958-021-00735-y.

Additional file 1: Figure S Representative images of mouse ovarian tissue grafts according to the duration of transplantation. The arrow indicate blood vessel.

\section{Acknowledgements}

The authors thank Jiaqiao Zhu and Zhutao Huang for their technical assistance with in vitro fertilization. We also thank Professor Hongcan Shi and Ying Zheng who supported the experimental installation.

\section{Availability of date and materials}

The dataset used in the current study is available from the corresponding author upon reasonable request.

\section{Authors' contributions}

The first author mainly participated in the design and implementation of the experiment and in writing of the manuscript. The other authors participated in the implementation of the experiment, and the corresponding author contributed to experimental design, experimental procedures, interpretation of results and article revision. The authors read and approved the final manuscript.

\section{Funding}

This work was supported by the National Key Research and Development Program of China (2017YFC1001602), the Special Fund for Provincial Key Research and Development Plan (BE2018685), National Nature and Science Fundation of China (81730041) and the Project of Jiangsu invigorating Health Care through Science, Technology and Education (YXZXB2016001), State Key Laboratory of Reproductive Medicine Funding (SKLRM-K201905).

\section{Declarations}

\section{Ethics approval and consent to participate}

The experimental protocols and animal handling procedures were approved and monitored by the Institutional Animal Care and Use Committee (IACUC) of Yangzhou University (SYXK (SU)2017-0044).

\section{Consent for publication}

Not applicable.

\section{Competing interests}

None of the authors report any conflict of interest.

\section{Author details}

${ }^{1}$ State Key Laboratory of Reproductive Medicine, Clinical Center of Reproductive Medicine, First Affiliated Hospital, Nanjing Medical University, Nanjing 210029, Jiangsu Province, China. ${ }^{2}$ Department of Obstetrics and Gynecology, Clinical Medical School of Yangzhou University, Yangzhou 225000, Jiangsu Province, China. ${ }^{3}$ Department of Obstetrics and Gynecology, Dalian Medical University, Dalian 116000, Liaoning Province, China. ${ }^{4}$ The kangda college of Nanjing medical university, Nanjing 210029, Jiangsu Province, China. ${ }^{5}$ Reproductive Medicine Center of Northern Jiangsu People's Hospital, Yangzhou University, Yangzhou 225000, Jiangsu Province, China.
Received: 4 July 2020 Accepted: 25 March 2021

Published online: 09 April 2021

\section{References}

1. Lee SJ, Schover LR, Partridge AH, Patrizio P, Wallace WH, Hagerty $K$, et al. American Society of Clinical Oncology recommendations on FP in cancer patients. J Clin Oncol. 2006:24(18):2917-31. https://doi.org/10.1200/JCO.2 006.06.5888

2. Andersen YC. Success and challenges in fertility preservation after ovarian tissue grafting [J]. Lancet. 2015;385(9981):1947-8. https://doi.org/10.1016/ S0140-6736(15)60960-6.

3. Oktay K, Sonmezer, et al. ovarian tissue banking for cancer patients. Hum Reprod. 2004;19(3):477-80. https://doi.org/10.1093/humrep/deh152.

4. Resetkova N, Hayashi M, Kolp LA, Christianson MS. Fertility preservation for Prepubertal girls: update and current challenges. Curr Obstet Gynecol Rep. 2013;2(4):218-25. https://doi.org/10.1007/s13669-013-0060-9.

5. Fisch B, Abir R. Female fertility preservation: past, present and future. Reproduction. 2018;156(1):F11-27. https://doi.org/10.1530/REP-17-0483.

6. Gandolfi F, Paffoni A, Brambilla EP, et al. Efficiency of equilibrium cooling and vitrification procedures for the cryopreservation of ovarian tissue: comparative analysis between human and animal models. Fertil Sterility. 2006:85(Supp-S1):1150-6.

7. Andersen CY, Bollerup AC, Kristensen SG. Defining quality assurance and quality control measures in connection with ovarian tissue cryopreservation and transplantation: a call to action [J]. Hum Reprod. 2018;33(7):1201-4. https://doi.org/10.1093/humrep/dey105.

8. Dolmans M M, Donnez J. Fertility Preservation in Women For Medical And Social Reasons: Oocytes Vs Ovarian Tissue [J]. Best practice \& research. Clinical obstetrics \& gynaecology, 2020

9. Abir R, Fisch B, Jessel S, Felz C, Ben-Haroush A, Orvieto R Improving posttransplantation survival of human ovarian tissue by treating the host and graft [J]. Fertil Sterility, 2011, 95(4):0-1210, 1205, DOl: https://doi.org/1 0.1016/j.fertnstert.2010.07.1082

10. Lee J, Kong HS, Kim EJ, et al. Ovarian injury during cryopreservation and transplantation in mice: a comparative study between cryoinjury and ischemic injury. Hum Reprod. 2016:dew144.

11. Jun $L$, Josiane, et al. Early massive follicle loss and apoptosis in heterotopically grafted newborn mouse ovaries. Hum Reprod (Oxford, England). 2002;17(3):605-11.

12. Mohanty JG, Jaffe JS, Schulman ES, Raible DG. A highly sensitive fluorescent micro-assay of $\mathrm{H} 2 \mathrm{O} 2$ release from activated human leukocytes using a dihydroxyphenoxazine derivative. J Immunol Methods. 1997;202(2):133-41. https://doi.org/10.1016/S0022-1759(96)00244-X.

13. Hamanaka RB, Chandel NS. Mitochondrial reactive oxygen species regulate cellular signaling and dictate biological outcomes. Trends Biochem Sci. 2010;35(9):505-13. https://doi.org/10.1016/j.tibs.2010.04.002

14. Israely $\mathrm{T}$. Reducing ischaemic damage in rodent ovarian xenografts transplanted into granulation tissue. Hum Reprod. 2006;21(6):1368-79. https://doi.org/10.1093/humrep/del010.

15. Abir R, Fisch B, Jessel S, Felz C, Ben-Haroush A, Orvieto R. Improving posttransplantation survival of human ovarian tissue by treating the host and graft. Fertil Steril. 2011;95(4):1205-10. https://doi.org/10.1016/j. fertnstert.2010.07.1082

16. Friedman O, Orvieto R, Fisch B, Felz C, Freud E, Ben-Haroush A, et al. Possible improvements in human ovarian grafting by various host and graft treatments. Hum Reprod. 2012;27(2):474-82. https://doi.org/10.1093/ humrep/der385.

17. Nugent D, Newton H, Gallivan L, Gosden RG. Protective effect of vitamin E on ischaemia-reperfusion injury in ovarian grafts. Reproduction. 1998;114(2): 341-6. https://doi.org/10.1530/jrf.0.1140341.

18. Mahmoodi M, Soleimani Mehranjani M, Shariatzadeh SMA, Eimani $\mathrm{H}_{\text {, }}$ Shahverdi A. N-acetylcysteine improves function and follicular survival in mice ovarian grafts through inhibition of oxidative stress. Reprod BioMed Online. 2015;30(1):101-10. https://doi.org/10.1016/j.rbmo.2014.09.013.

19. Suzuki $H$, Ishijima $T$, Maruyama S, Yanagimoto Ueta $Y$, Abe $Y$, Saitoh $H$. Beneficial effect of desialylated erythropoietin administration on the frozenthawed canine ovarian xenotransplantation. J Assist Reprod Genet. 2008; 25(11-12):571-5. https://doi.org/10.1007/s10815-008-9271-9.

20. Das DK, Maulik N. Resveratrol in cardioprotection: a therapeutic promise of alternative medicine. Mol Interv. 2006;6(1):36-47. 
21. Taguchi A, Wada-Hiraike O, Kawana K, Koga K, Yamashita A, Shirane A, et al. Resveratrol suppresses inflammatory responses in endometrial stromal cells derived from endometriosis: a possible role of the sirtuin 1 pathway. J Obstet Gynaecol Res. 2014;40(3):770-8. https://doi.org/10.1111/jog.12252.

22. Borges SC, Ferreira, Botura PE, Da Silva LM, et al. Evaluation of the treatment with resveratrol-loaded nanoparticles in intestinal injury model caused by ischemia and reperfusion. Toxicology. 2018;396-397:13-22. https://doi.org/1 0.1016/j.tox.2018.02.002.

23. Banu SK, Stanley JA, Sivakumar KK, Arosh JA, Burghardt RC. Resveratrol protects the ovary against chromium-toxicity by enhancing endogenous antioxidant enzymes and inhibiting metabolic clearance of estradiol. Toxicol Appl Pharmacol. 2016;303:65-78. https://doi.org/10.1016/j.taap.2016.04.016.

24. Li CY, Zhao YH, Hao HS, Wang HY, Huang JM, Yan CL, et al. Resveratrol significantly improves the fertilisation capacity of bovine sex-sorted semen by inhibiting apoptosis and lipid peroxidation. Sci Rep. 2018;8(1):7603. https://doi.org/10.1038/s41598-018-25687-z.

25. Ozcan P, Ficicioglu C, Yildirim OK, et al. Protective effect of resveratrol against oxidative damage to ovarian reserve in female Sprague-Dawley rats. Reprod BioMed Online. 2015;31(3):404-10. https://doi.org/10.1016/j.rbmo.2 015.06.007.

26. Jie, Hao, Astrud, et al. Resveratrol supports and alpha-naphthoflavone disrupts growth of human ovarian follicles in an in vitro tissue culture model [J]. Toxicology \& Applied Pharmacology, 2018.

27. Youm HW, Lee JR, Lee J, Jee BC, Suh CS, Kim SH. Optimal vitrification protocol for mouse ovarian tissue cryopreservation: effect of cryoprotective agents and in vitro culture on vitrified-warmed ovarian tissue survival. Hum Reprod. 2014;29(4):720-30. https://doi.org/10.1093/humrep/det449.

28. Lee J, Kim EJ, Kong HS, Youm HW, Lee JR, Suh CS, et al. A combination of simvastatin and methylprednisolone improves the quality of vitrifiedwarmed ovarian tissue after auto-transplantation. Hum Reprod. 2015;30(11): 2627-38. https://doi.org/10.1093/humrep/dev222.

29. Eyck ASV, Jordan BF, Gallez B, et al. Electron paramagnetic resonance as a tool to evaluate human ovarian tissue reoxygenation after xenografting. Fertil Sterility. 2009;92(1):374-81. https://doi.org/10.1016/j.fertnstert.2008.05. 012.

30. Lundy T, Smith P, O"Connell A, et al. Populations of granulosa cells in small follicles of the sheep ovary [J]. Reproduction, 1999, 115(2):251-262, DOI: https://doi.org/10.1530/jrf.0.1150251.

31. Kalogeris $T$, et al. Cell biology of ischemia/reperfusion injury. Int Rev Cell Mol Biol. 2012;298:229-317. https://doi.org/10.1016/B978-0-12-394309-5. 00006-7.

32. Luciana C, Daniel MD, Andrade AC, et al. In vivo characterization of metabolic activity and oxidative stress in grafted human ovarian tissue using microdialysis. Fertil Sterility. 2018:S0015028218303340.

33. Fabbri R, Macciocca M, Vicenti R, Pasquinelli G, Caprara G, Valente S, et al. Long-term storage does not impact the quality of cryopreserved human ovarian tissue. Journal of Ovarian Research. 2016;9(1).

34. Zhao Q, Zhang Y, Su K, et al. Vitrification freezing of large ovarian tissue in the human body. J Ovarian Res. 2019; 12(1): 77. Published 2019 Aug 22.

35. Gumus, Erkan, Kaloglu, et al. Effects of vitrification and transplantation on follicular development and expression of EphrinB1 and PDGFA in mouse ovaries [J]. Cryobiology International Journal of Low Temperature Biology \& Medicine, 2018

36. Behringer R. Mouse Ovary Transplantation. Cold Spring Harbor Protocols. 2017;(3):pdb.prot094458.

37. Lee J, Lee JR, Youm HW, Suh CS, Kim SH. Effect of preoperative simvastatin treatment on transplantation of cryopreserved-warmed mouse ovarian tissue quality. Theriogenology. 2015;83(2):285-93. https://doi.org/10.1016/j. theriogenology.2014.09.027.

38. Yang $Y$, Wu Z Z, Cheng $Y L$, et al. Resveratrol protects against oxidative damage of retinal pigment epithelium cells by modulating SOD/MDA activity and activating Bcl-2 expression [J]. 2019.

39. Malaguarnera. Influence of Resveratrol on the Immune Response [J]. Nutrients, 2019, 11(5).

40. Hsu H, Xiong J, Goeddel DV. The TNF receptor 1-associated protein TRADD signals cell death and NF-kappa B activation. Cell. 1995;81(4):495.

41. Csiszar A, Labinskyy N, Podlutsky A, Kaminski PM, Wolin MS, Zhang C, et al. Vasoprotective effects of resveratrol and SIRT1: attenuation of cigarette smoke-induced oxidative stress and proinflammatory phenotypic alterations. Am J Physiol Heart Circ Physiol. 2008;294(6):H2721-35. https://doi.org/10.11 52/ajpheart.00235.2008.
42. Alves-Fernandes DK, Jasiulionis MG. The Role of SIRT1 on DNA Damage Response and Epigenetic Alterations in Cancer. Int J Mol Sci. 2019;20:13.

43. Li F, Tao Y, Zhang Y, Li Y, Fang F, Liu Y, et al. Follicle growth and oocyte development after ovary transplantation into back muscle of immune-intact adult castrated male mice. Reproduction. 2010;140(3):465-76. https://doi. org/10.1530/REP-10-0076.

\section{Publisher's Note}

Springer Nature remains neutral with regard to jurisdictional claims in published maps and institutional affiliations.
Ready to submit your research? Choose BMC and benefit from:

- fast, convenient online submission

- thorough peer review by experienced researchers in your field

- rapid publication on acceptance

- support for research data, including large and complex data types

- gold Open Access which fosters wider collaboration and increased citations

- maximum visibility for your research: over $100 \mathrm{M}$ website views per year

At $\mathrm{BMC}$, research is always in progress.

Learn more biomedcentral.com/submissions 